Relations industrielles

Industrial Relations

\title{
Stokdyk, Architect of Cooperation, by Joseph G. KNAPP, American Institute of Cooperation, 1953, 229 pp.
}

\section{Charles Lemelin}

Volume 10, numéro 1, décembre 1954

URI : https://id.erudit.org/iderudit/1022794ar

DOI : https://doi.org/10.7202/1022794ar

Aller au sommaire du numéro

Éditeur(s)

Département des relations industrielles de l’Université Laval

ISSN

0034-379X (imprimé)

1703-8138 (numérique)

Découvrir la revue

Citer ce compte rendu

Lemelin, C. (1954). Compte rendu de [Stokdyk, Architect of Cooperation, by Joseph G. KNAPP, American Institute of Cooperation, 1953, 229 pp.] Relations industrielles / Industrial Relations, 10(1), 61-64.

https://doi.org/10.7202/1022794ar

Tous droits réservés (C Département des relations industrielles de l’Université Laval, 1954
Ce document est protégé par la loi sur le droit d'auteur. L’utilisation des services d'Érudit (y compris la reproduction) est assujettie à sa politique d'utilisation que vous pouvez consulter en ligne.

https://apropos.erudit.org/fr/usagers/politique-dutilisation/ 


\section{LIVRES et REVUES}

Histoire du mouvement ouvrier, Edouard Dolleans, Tome III, 1 vol. 424 pp., Librairie Armand Colin, Aux Editions Ouvrières, 1019 , rue St-Denis, Montréal, $\$ 4.95$.

Cet ouvrage clot la série entreprise par l'auteur décédé en septembre dernier et couvre la période 1921 à nos jours. Le grand historien du mouvement ouvrier entreprend ici une synthèse de l'évolution du syndicalisme depuis la première grande guerre dans notre monde occidental: le grand espoir de la révolution russe, la naissance du fascisme, la crise économique de 1929 , le New-Deal américain, la guerre de 1939, le travailleur anglais, le syndicalisme en Russie, l'évolution du syndicalisme américain, la rupture de l'internationale, etc. Malgré l'expérience et les longues études de l'auteur, il était très difficile en quelques centaines de pages d'approfondir une matière aussi vaste et aussi compliquée. Cette déception est cependant amplement compensée par l'esprit qui se dégage de l'ensemble de l'ouvrage et certains chapitres comme «valeurs humaines face aux idéologies ». Ce qui fait l'intérêt de l'oeuvre de Dolléans, ce n'est pas tant l'étude des institutions par lesquelles s'est exprimé le mouvement ouvrier que la mise en valeur du rôle important qu'ont joué les travailleurs eux-mêmes ainsi que leurs chefs dans l'ascension des classes laborieuses. «Les militants ouvriers, dit-il, ont une importance non pas anectodique, mais historique: ils incarnent les sen'iments. les révoltes et les espoirs de tant d'obscurs travailleurs qui forment les classes laborieuses. Les militants ouvriers ont été à la fois des interprètes et des créateurs; car tout homme d'action n'est jamais ni complètement libre, ni complètement esclave; il vit dans son temps et de son temps; mais si son humanité est profonde. il découvre en elle la vision des lendemains possibles entre lesquels il choisit ».

Il nous montre aussi un aspect très important de la réalité sociale qui détruit à sa base la doctrine du matérialisme historique préconisée par Marx et soutenue de nos jours par les commu- nistes. «Les complexités humaines nous découvrent une vision pluraliste des choses et des êtres. Nous avons une tendance à substituer à des réalités, des illusions propres à flatter le favoritisme de nos passions, la déviation partisane de nos intérêts. Et ainsi, nous en arrivons à nous duper nous-mêmes et à tromper les autres 》. (p. 16). « Aujourd'hui l'histoire prend à la gorge nos générations et ces jeunesses dont nous rapproche une commune angoisse, il nous paraît essentiel, avant toute autre chose, de voir clair, et afin d'aider les jeunes à un examen lucide, d'élargir notre horizon aux proportions du monde. $\mathrm{Au}$ cours de cette longue et douloureuse histoire les classes ouvrières se sont émancipées et ont atteint leur maturité. Et, si nous disons les classes ouvrières, c'est que vouloir la considérer comme un bloc contredit la réalité, le pluralisme des courants $\mathrm{e}^{\mathrm{t}}$ la diversité des tendances... L'uniformité des couches successives qui composent la classe ouvrière est une fiction, une idéologie modelée à des fins politiques.» (pp. 406-407).

Le lecteur canadien sera peut être un peu perdu dans les dédales du développement européen de cette His.oire du Mouvement Ouvrier, trouvera trop sommaires et trop superficielles les pages consacrées au syndicalisme américain, mais il ne manquera pas de voir plus clair et d'avoir une meilleure compréhension de ce phénomène social que lon a caractérisé, à juste titre, comme le plus important des temps modernes.

$$
\text { G.D. }
$$

Stokdyk, Architect of Cooperation, by Joseph G. KNAPP, American Institute of Cooperation, 1953, $229 \mathrm{pp}$.

Dans la première section de cet ouvrage, monsieur Joseph G. Knapp retrace dans l'ordre chronologique les principaux évènements de la vie de Stokdyk. On voit celui-ci agir tour à tour comme biologiste, spécialiste en marché, candidat au doctorat en économie, professeur à l'université, homme de recherche, puis finalement comme «leader 》 en coopération. L'analyse de son action dans cette sphère occupe la dernière moitié de cette partie de l'étude. On y voit Stokdyk aux prises avec une multitude de problèmes: problèmes de recherche, dorganisation, de finance, de relations humaines. Il nous apparaît alors comme le type idéal de l'administrateur. Soucieux de tenir compte de 
façon systématique et rigoureuse de tous les éléments en cause et en même temps avide d'action.

That Stok was a brilliant man, it would be hard to deny. His academic and professional record speaks for itself. Whatever he did, he did superbly, and while he was always striving for perfection he measured the cost in terms of other values.

Bien qu'il ne fut pas un scientiste, Stokdyk en a transposé la discipline dans l'exécution de son programme d'action coopérative. Il semble qu'il possédait toutes les qualités d'esprit qui font les savants. Il eût pu être pathologiste, agronome, biologiste, économiste, et $\mathrm{y}$ briller aux premiers rangs. Mais il a choisi d'être un homme d'action sur le plan social. Il attaque ainsi le problème humain de façon pratique et sur tous les fronts. Cette diversification intellectuelle à laquelle il doit se soumettre pour se livrer à cette action compréhensive n'aboutit pas dans le superficiel. Le palier moyen de connaissances et d'érudition qu'il adopte et d'où il peut attaquer les problèmes qui lui sont chers et faire rayonner son action se situe bien au-delà de la vulgarité. Il reste un esprit supérieur. Telle est l'impression qui reste de la lecture de sa biographie par monsieur Knapp.

Dans la première partie du volume l'auteur s'appuie constamment et largement sur les écrits et les témoignages des hommes qui ont travaillé avec Stokdyk et l'ont connu de près. Bien que les citations soient abondantes, elles sont tellement à point et bien agencées que la lecture reste facile et convaincante. Le rôle effacé qu'a voulu se donner l'auteur crée une atmosphère qui fait certes apprécier davnntage l'objectivité de la présentation des faits et des témoignages. Toutefois, en faisant sa synthèse au centre de l'étude, M. Knapp aurait dû abandonner cette technique, mettre de côté son souci de modestie et présenter une interprétation plus personnelle. Car M. Knapp est plus que l'historien de Stokdyk, il en est l'ami intime. En lisant cette synthèse on se sentirait plus près du héros si M. Knapp y avait mis plus de lui-même.

Que dire de la philosonhie de Stokdyk, en particulier de sa philosophie de la coopération telle qu'elle apparaît dans la sélection de documents signés de sa main et qui constituent la dernière partie du livre?

Pour la caractériser d'un mot, disons que sa pensée est dynamique. Elle prend graduellement plus d'ampleur et de précision. Nul doute que s'il eût vécu plus longtemps ses préoccupations intellectuelles l'eussent conduit au seuil des problèmes où aboutissent tous les esprits philosophiques. C'est du moins ce que laisse présager l'étude de sa pensée sur le plan de la coopération.

On a défini Stokdyk comme «the strong man in agricultural cooperation.... Il admet que les coopératives agricoles sont d'abord ordonnées au bien des fermiers:

...we recognize that cooperatives restrain trade and competition. That is one of their legitimate objectives. Every partnership, every corporation, and every labor union restrains competition to some extent - so does every cooperative. .....we accept the fact that pure competition, as pictured by the classical economists, is almost nonexistent and that we are living in a world where the group bargain, rather than the individual bargain, dominates...

Toutefois, les coopératives agricoles de marché n'ont de raison d'être que parce qu'elles sont ultimement ordonnées au bien commun:

It is in the public interest that agricultural products be marketed efficiently, and farm supplies purchased economically... since both producers and consumers gain when efficiency in agricultural production or marketing is increased.

...farmers' cooperatives, like all cooperatives, are a tool to curb monopolies and a method of introducing needed correctives in our competitive system of free enterprise. They have other objectives which also are in the public interest. Although their immediate objective is to improve status of their members, they have introduced many efficiencies in the marketing of farm products and the handling of farm supplies. The benefit of improvements in a highly 
competitive enterprise such as agriculture soon passes to consumers; hence, there is a. market public interest in efficient production and marketing.

C'est au nom de l'intérêt public que les coopératives sont explicitement protégées dans la législation anti-combines. C'est pour la même raison qu'elles sont exemptées de certaines règles imposées aux monopoles, comme les règles touchant la fixation des prix. Toutefois,

This does not give associations of farmers the right to join with competitors in restraint of trade...but does give them the right to introduce needed corrections in the capitalistic competitive system.

Bien qu'il tînt à ce que le statut des coopératives fût reconnu au nom de l'intérêt public, il n'entendait pas faire des coopératives des parasites du gouvernement.

La Bank for Cooperatives, instituée en 1933 comme partie d'un plan d'ensemble de politiques en matière de crédit agricole, opérait sous le contrôle étroit du gouvernement et avec des capitaux fournis à même les fonds publics. Stokdyk voulait que le contrôle et le capital passât graduellement aux mains des usagers, i.e. des coopératives agricoles. Il écrivait en 1935:

The fundamental principle upon which all the Farm Credit Agencies are built is that they are not designed to advance charity to the American farmer who, incidentally, has never asked for it. On the contrary, the Farm Credit Administration has been built with the single purposes of helping the farmer to help himself.

Président d'une des douze Banks for Coopératives, il avait aussi des idées bien précises sur l'esprit qui devait animer les responsables de ces institutions.

The ultimate test of our services to cooperative enterprise is based upon our understanding of the economics of cooperative loans. If we make unsound loans, we will be given little credit for developing procedures and policies or conforming to legal requirements. On the other hand, if we pass up sound loans because we do not comprehend the economic phases, we fail to render maximum service.

Il s'opposait à une ingérence trop directe du congrès dans les affaires de la Banque. Il s'opposait à une telle centralisation parce qu'il y voyait un danger de porter atteinte au caractère démocratique que doit afficher toute institu'ion coopérative.

D'ailleurs pour lui la coopération n'était pas une forme de socialisme mais bien un palliatif aux lacunes et aux abus du système capitaliste.

Some forecast a tug of war between unlimited free enterprise fhich ends in monopoly on the one hand, and State socialism on the other. I do not believe the issue will be as clearcut as that. My guess is that we will continue to experiment with many types of economic organization and that two will develop rapidly... These two are public utilities and cooperatives. Both types of organization preserve individual initiative yet limit the profits of the corporate entity.

Sa conception de la démocratie était bien nette.

We talk of equality in a democracy - but it is only political equality, and that to the extent that each has the right to exercise one vote. Economic equality, and social equality do not exist because personal qualities are not equal.

Son enthousiasme pour les principes coopératifs ne l'empêchait pas de reconnaître la nécessité du profit comme stimulant à l'activité économique.

The combination of dexterity and industry in an individual makes him a valuable member of society. But to foster industry and to induce the individual to develop his dexterity we need incentives. No long-time satisfactory substitute has ever been found for the economic incentive of private property.

Communism has as its motto "From each according to his ability and to each according to his needs". But Communism soon breaks down 
wherever tried, because no one wants to do the dirty work or exert himself strenuously. Communistic societies soon revert to the capitalistic principle, "From each according to his ability and industry and to each according to his ability and industry". Attractive as the doctrine of Communism fight be, no society has been able to distribute wealth according to its tenets without destroying individual initiative.

Un catholique aimerait évidemment voir sous la plume de Stokdyk des considérations qui dépassent le plan matériel du communisme et du libéralisme. Il est encore malheureux qu'il ait affirmé que le droit de propriété n'est pas un droit naturel mais le fruit d'une «sanction sociale». On regrette que, pris dans l'action comme il l'a été, il n'ait pas poussé davantage ses réflexions sur l'homme, l'homme tout entier, l'homme qui a su être lui-même en consacrant sa vie au service des autres. Il aurait réalisé à partir de sa propre expérience que, pour une élite au moins, lidéal de service est un stimulant capable de conduire à de fécondes réalisations.

\section{Charles Lemelin}

Voluntary Medical Care Insurance - A Study of non-profit plans in Canada. Ottawa, 1954, Research Division, Department of National Health and Welfare, 208 pp. Multilith.

On parlait à peine il y a quinze ans de l'assurance-santé. A part la Croix Bleue qui offrait une assurance-hospitalisation, à peu près rien ne se faisait au Canada dans ce genre d'assurance. Puis en 1937, nait le premier service d'assurance-maladie et d'autres de 1939 jusqu'à 1946, année où l'on voit l'éclosion de cinq des quatorze services actuellement en existence.

C'est l'histoire, l'organisation et le financement de ces services d'assurancemaladie qu'étudie cette publication due au Service de la recherche du Ministère de la santé nationale et du bien-être, qui a confié à John Osborne, économiste attaché au Service, le soin de préparer et rédiger ce travail.
Après un chapître consacré à l'historique de l'organisation de ces services, les débuts timides de l'avant-guerre, l'affermissement pendant la guerre et l'expansion formidable dans l'aprèsguerre, où l'on voit que le nombre de participants actifs et leurs dépendants passer de 13,000 en 1939 à plus de $2,000,000$ en 1953, l'auteur étudie longuement l'organisation de ces plans, qu'il divise en deux catégories: l'assurance service et l'assurance indemnité. Les sociétés d'assurance-service s'engagent comme dit l'auteur «to pay the full cost of medical care services rendered to their members. The latter plans usually enter into contracts with doctors (or their professional associtions) who agree to accept the fees paid by the plans as full payment for services rendered 》 (page 21) alors que les sociétés d'assurance indemnité «guarantee to reimburse the individual member for his medical care expenses up to a certain fixed maximum sums for each type of service received, and do not enter into contracts with doctors to accept the amounts paid by the plans as full payment for services rendered (ibidem).

Nous connaissons dans la province de Québec deux sociétés d'assurance-santé, Les Services de santé de Québec et la Quebec Hospital Service Association, établie comme service d'assurance-santé après plusieurs années de fonctionnement comme service d'assurances-hospitalisation. La première offre de l'assurance service et la seconde de l'assurance indemnité.

Les troisième et quatrième chapitres sont consacrés à l'étude du financement des sociétés et de l'utilisation des services offerts. Une étude complète, détaillée et précise de tous les aspects: revenus, dépenses, bénéfices, administration, paiements aux médecins, quantité et valeur des services utilisés.

L'étude soignée et bourrée de chiffres et de faits indigestes, se termine par une conclusion qui offre un bon résumé, une excellente vue d'ensemble de la situation.

Regrettons que la présentation des tableaux soit aussi peu soignée, ce qui les rend difficiles à consulter.

JAMES Hodgson 